\title{
THE TEACHER AS THE MOST IMPORTANT MOTIVATIONAL FACTOR IN THE EFL CLASSROOM
}

\begin{abstract}
The goal of this paper is to highlight the issue of motivation in foreign language learning and to focus on the links between students' motivation and the teacher. By involving students, arousing and maintaining students' interest and providing effective feedback, teachers can build students' intrinsic motivation which is a key to learning a foreign language. For example, teachers can motivate students by allowing them to choose more frequently. Teachers may employ various strategies in order to create a positive learning atmosphere that enhances students' self-esteem and motivation such as cooperative learning techniques/activities, higher-order thinking skills or even games. Finally, by developing students' language learning strategies teachers can build learner autonomy which leads to sustained motivation in learning. To illustrate the above-mentioned points, examples of self-evaluation, use of games, use of higher-order thinking skills, a written feedback form and a marking rubric have been provided.
\end{abstract}

Keywords: language, learning, motivation, students, teacher.

\section{NASTAVNIK KAO NAJVAŽNIJI FAKTOR MOTIVACIJE U NASTAVI STRANOG JEZIKA}

\begin{abstract}
APSTRAKT
Cilj rada je da ukaže na značaj koncepta motivacije u nastavi stranog jezika i nastavnika kao ključnog faktora motivacije učenika. Uključivanjem u rad svih učenika, postizanjem i održavanjem stepena zainteresovanosti učenika i efikasnim pružanjem povratnih informacija, nastavnik je u stanju da utiče na rast unutrašnje motivacije učenika koja je ključ za učenje stranog jezika. Na primer, nastavnik može da motiviše učenike tako što će im omogućiti da što češće biraju (teme, aktivnosti, domaće zadatke, vokabular, rad u paru ili grupi). Nastavnik takođe može da koristi različite strategije sa ciljem da stvori pozitivno okruženje koje podstiče samopouzdanje i motivaciju učenika kao što su tehnike kooperativnog učenja, aktivnosti koje podstiču razvoj kritičkog mišljenja pa čak i igre. Konačno, razvijanjem strategija
\end{abstract}


učenja stranog jezika, nastavnik je u stanju da direktno utiče na jačanje autonomije učenika koja vodi stalnoj motivaciji u učenju. Kao ilustraciju, autor navodi primere samo-ocenjivanja, upotrebe igara, upotrebe kritičkog mišljenja, formulara za pružanje povratnih informacija i rubriku odnosno kriterijumsko-referentnu listu za ocenjivanje.

Ključne reči: jezik, učenje, motivacija, učenici, nastavnik.

\section{INTRODUCTION}

There are many factors which affect our students' motivation and involvement. Most things are beyond our control as language teachers and fall outside the confines of the few lessons that we have with students in a week. Home background, physical tiredness, events in their personal life, health, previous educational experience, personality and adolescence issues are just some of the factors that can affect how individual students appear to us in our classes.

So, the starting point should be to try to understand why some students are uninterested and not motivated, and not simply to blame them for not being interested. If we start from the assumption that all human beings in the right circumstances are naturally motivated to learn, we need to ask ourselves: Where does that motivation go? What can we do to help our students regain motivation? Can a teacher provide extrinsic motivation where intrinsic motivation is lacking?

\section{THE ROLE OF THE LANGUAGE TEACHER}

Students' motivation is significantly affected by the teacher. In fact Dörnyei (2001a:120) points out some studies on motivation have concluded that the teacher is the "most important ... motivational factor in the classroom". Students tend to learn more about something they like and find interesting than about something that holds no appeal for them (Scarcella and Oxford 1992:33). A class that is lively and fun is better than one that is boring or tense. It is also helpful if students find the teacher encouraging and friendly and if the class environment is as nonthreatening as possible (Littlewood 1984:58-59).

Dörnyei (2001a:120) categorizes the influences a teacher has on student motivation as follows:

- personal characteristics: teacher can motivate students through characteristics such as being committed and personally warm.

- teacher immediacy: teachers can motivate students by coming physically closer (e.g. walking around the class instead of always staying at the front) 
and psychologically closer (e.g. knowing students' names and personalizing topics).

- active motivational socializing behaviour: teachers can motivate students through behaviours such as presenting clear goals and tasks, giving positive feedback and encouraging students.

- classroom management: teachers can motivate students through such things as maintaining a sense of order in the classroom and ensuring that students maintain norms of appropriate (non-disruptive) behaviour.

Teachers can reduce the sense of threat in the classroom by creating a positive learning atmosphere that enhances students' self-esteem and motivation. Teachers can contribute to such an atmosphere by smiling, offering praise and encouragement and bringing humour and laughter into the classroom. However, there should be a balance in the classroom atmosphere. In setting the tone of a class, an element of challenge and pressure can be useful; in fact, motivation tends to be enhanced by tasks in which the goal is relatively challenging, though not so difficult that students perceive it as being impossible (Dörnyei 2001b:84). Thus, the classroom atmosphere should be warm and encouraging as well as challenging.

In motivation, one key factor is the expectation that one can reasonably hope to succeed in a task. In other words, people who think they have a chance of success in a task are more likely to continue investing effort in it than those who think that they have no hope of success (Dörnyei 2001a:20). From this it follows that teachers must constantly encourage students and remind them that ultimately the road to success lies mainly in sustained effort.

Even though teachers may provide plenty of encouragement and employ various strategies to relax the classroom atmosphere, there will still be some quieter or weaker students who will choose not to respond or participate. One element of treating students with respect is allowing them the freedom to make choices and beyond a certain point further intervention on teacher's part may do more harm than good by creating fear and tension (or simply wasting time that could have been better spent on other students who are more willing to respond).

Teacher can also build students' confidence to speak. For those weaker students who are not yet confident to express their ideas in English with a passable degree of fluency and accuracy, every sentence they utter may lead to fear of sounding incompetent or even stupid. These students face two challenges: the challenge of figuring out what to say and the challenge of deciding how to say 
it. Teachers can make it easier for students to speak out in English by reducing the difficulty of these two challenges. In other words, if they:

- ask questions that only require a yes/no answer or questions that allow students to respond with a single-word sentence;

- allow students to prepare their responses by thinking about the question silently for a minute and jotting down a few notes;

- allow students to rehearse their responses in pairs or small groups by surveying each other quickly on the question asked.

Either of these methods allows students a little time to formulate and even practise answers in pairs or small groups.

Common European Framework of Reference for Languages (CEFR) published by the Council of Europe (2001) also acknowledges the important role of language teachers:

Teachers should realise that their actions, reflecting their attitudes and abilities, are the most important part of the environment for language learning/acquisition. They present role-models which students may follow in their future use of the language and their practice as future teachers. (CEFR, 2001:144)

According to the CEFR, teacher's competences reflect the following combination of knowledge and skills: teaching skills, classroom management skills, the ability to engage in action research and to reflect on experience, teaching style, understanding of and ability to handle testing, assessment and evaluation, knowledge of and ability to teach sociocultural background information, inter-cultural attitudes and skills, ability to deal with individualisation within classes containing diverse learner types and abilities. (CEFR, 2001:144).

The CEFR also points out learner's different competences, and among these, affective factors such as involvement and motivation. Successful task performance is more likely where the learner is fully involved. A high level of intrinsic motivation to carry out the task - due to interest in the task or because of its perceived relevance, for example to real life needs or to the completion of another linked task (task interdependence) - will promote greater learner involvement. Extrinsic motivation may also play a role, for example where there are external pressures to complete the task successfully (e.g. to earn praise or in order not to lose face, or for competitive reasons). (CEFR, 2001:161) 


\section{BUILDING INTRINSIC MOTIVATION}

Brown (2007) argues that teachers should try to build students' intrinsic motivation as much as possible, and he provides the following checklist of criteria that can be applied to a language teaching technique (activity) in order to determine whether it promotes intrinsic motivation:

- "Does the technique appeal to the genuine interests of the students? Is it relevant to their lives?

- Do you present the technique in a positive, enthusiastic manner?

- Are students clearly aware of the purpose of the technique?

- Do students have some choice in choosing some aspect of the technique and determining how they go about fulfilling the goals of the technique?

- Does the technique encourage students to discover for themselves certain principles or rules (rather than simply being told)?

- Does it encourage students in some way to develop or use effective strategies of learning and communication?

- Does it contribute - at least to some extent - to students' ultimate autonomy independence from you?

- Does it foster cooperative negotiation with other students in the class? Is it truly interactive?

- Does the technique present a reasonable challenge?

- Do students receive sufficient feedback on their performance (from each other or from you)?" (Brown, 2007:93)

Teachers can build intrinsic motivation by involving students, arousing and maintaining students' interest and providing effective feedback.

\subsection{Involving students}

If motivation is a key to learning, then student involvement is a key to motivation, thus learning. Teachers can build intrinsic motivation by involving students and allowing them to: choose the seating arrangement, select the pairs or groups, speak to each other, (pairwork / groupwork), look at each other during an activity (pairwork / groupwork), decide when to stop an activity, select the vocabulary, spell out new words, write on the board, check the work, compare their answers, give the instructions, ask the comprehension questions, repeat what has been said (if others have not heard it), give dictation, tell stories, choose homework assignments, have group or paired tests now and again, evaluate their 
own work (see Table 1), evaluate each other's work, operate the equipment, etc. Also, teachers must allow students to have certain input into the choice of topics, choice or design of activities and preparation of activities or materials. Dörnyei (2001b:78) summarises this as Strategy 19: Make learning stimulating and enjoyable for the learners by enlisting them as active task participants.

\begin{tabular}{|l|c|c|c|}
\hline $\begin{array}{l}\text { Evaluate yourself in the following aspects of learning a foreign } \\
\text { language }\end{array}$ & $\odot$ & $*$ \\
\hline 1. Reading & $\square$ & $\square$ & $\square$ \\
\hline 2. Listening & $\square$ & $\square$ & $\square$ \\
\hline 3. Speaking & $\square$ & $\square$ & $\square$ \\
\hline 4. Writing & $\square$ & $\square$ & $\square$ \\
\hline 5. Vocabulary & $\square$ & $\square$ & $\square$ \\
\hline 6. Grammar & $\odot$ & $\ominus$ & $\ominus$ \\
\hline $\begin{array}{l}\text { Also evaluate yourself in the following aspects related to } \\
\text { successful learning of foreign languages }\end{array}$ & $\square$ & $\square$ & $\square$ \\
\hline 7. Working independently & $\square$ & $\square$ & $\square$ \\
\hline 8. Thinking creatively and critically & $\square$ & $\square$ & $\square$ \\
\hline 9. Motivation and self-esteem & $\square$ & $\square$ & $\square$ \\
\hline 10. Taking on responsibility & $\square$ & $\square$ & $\square$ \\
\hline 11. Being actively involved & $\square$ & $\square$ & $\square$ \\
\hline 12. Taking risks & $\square$ & $\square$ & $\square$ \\
\hline 13. Willingness to cooperate and assist others & $\square$ & $\square$ & $\square$ \\
\hline 14. Group interaction, mutual respect and tolerance & $\square$ & $\square$ & $\square$ \\
\hline 15. Listening actively & $\square$ & $\square$ & $\square$ \\
\hline 16. Doing homework and self-study book regularly & $\square$ & $\square$ & $\square$ \\
\hline 17. Positive attitudes toward the subject and school & & \\
\hline $\begin{array}{l}\text { Student's } \\
\text { name }\end{array}$ & $\square$ \\
\hline
\end{tabular}




\subsection{Arousing and maintaining students' interest}

Teachers can build students' intrinsic motivation by arousing and maintaining students' interest which involves variation of all kinds: the type of interaction pattern (individual, whole class, pairwork, groupwork), full participation, the type of input (listening/ reading /visual material), the type of activity (communicative, creative, open-ended, game), the use of higher-order thinking skills. Dörnyei (2001b:75) summarises this as Strategy 17: Make learning more stimulating and enjoyable by breaking the monotony of classroom events.

For several reasons above mentioned, teachers must incorporate cooperative learning techniques/activities into their teaching style. Using such techniques in the language classroom can be quite effective not just because they engage students in meaningful interactions with one another but also because they lead to the reduction of anxiety, the increase of student self-esteem, selfconfidence and motivation, the greater frequency and range of input and output opportunities, the development of cross-cultural and inter-social understanding and greater learner-centredness (Crandall, 1999) One of the most effective cooperative learning techniques is the Jigsaw (Aronson et al, 1978). This technique combines several important aspects of learning including reading comprehension, speaking (oral presentation), and cooperative learning (smallgroup work). It can include writing as well. In a typical Jigsaw reading activities, students are divided into small groups, and each group is assigned different reading material (different part of the same text or different texts). After reading, students discuss the material in their groups to become fully familiar with the piece. Then groups are re-formed so that each new group includes students who have read different materials. In their new groups, students share what they have read with other students. A notable strength of this activity is that it allows students to contribute to discussions (in re-formed groups) as experts on their own piece which fosters respectful relationships among students.

In-class work should be organized in pairs or small groups as often as possible because this arrangement allows more students to practise at the same time. Pairs are the most efficient grouping in that they allow the most students to talk at once, but as Harmer (2001:120) notes, the effectiveness of any pair work is affected quite a bit by how the two students get along. Small groups (of 3 or 4 students) still give many students an opportunity to speak but provide a bit more space for personality differences. For example, in a small group, the presence of 
at least two other people means that a shy student can sit back and listen most of the time but still feel like a participant. As Ur (1981:7) points out, "the motivation of participants also improves when they work in small groups" so they provide a good environment for encouraging reluctant students to make their first attempts at speaking.

Using higher-order thinking skills can help building students' intrinsic motivation. Activities based on simple recall or knowledge of isolated forms and meanings tend to be boring whereas activities which are based on higher-order thinking skills are likely to be more interesting.

Task examples for vocabulary include classifying, generalizing and inserting (an appropriate conjunction). Task examples for grammar include gapfill, sentence-completion items etc. Task examples for reading or listening comprehension include making inferences from the text, drawing conclusions and making reasonable predictions that lead to analytical judgements by answering 'Why', 'How', 'What do you think' type of questions (see Figure 1).

Task 1: Students read a short text about Pareto's Principle and answer the two questions: 1) How true do you think this is? 2) What methods can shops use to maximize the sales of goods in the other $80 \%$ of their range?

\section{Pareto's Principle}

Also known as the 'eighty-twenty' rule, Pareto's Principle says that $80 \%$ of a company's profits come from $20 \%$ of its activities. In the case of a supermarket, four fifths of its sales will come from one fifth of its product range. It is a common phenomenon which applies to many businesses.

Task 2: Students draw a pie chart showing how Pareto's Principle works in retail. In order to be able to understand the principle they must understand what the numbers 80 and 20 really represent by writing 20 inside the bigger pie i.e. 80 inside the smaller part ${ }^{2}$ and providing appropriate explanation.

Figure 1: An example of the use of higher-order thinking skills ${ }^{3}$

${ }^{2}$ Because $80 \%$ of a retail outlet's profits come from $20 \%$ of its sales and vice versa $20 \%$ of its profits come from $80 \%$ of its sales.

${ }^{3}$ The author's idea 
Another way to build students' intrinsic motivation is by using games which add the element of fun to learning. For instance, a well-known game Crosses \& Noughts can be utilized as an exciting activity for reviewing and recycling vocabulary (after each unit or two units). Students are divided into two teams: team A and team B. The teacher draws a grid of three squares by three squares on the board and writes a letter in each square. Each letter represents a key vocabulary item (noun or verb) which is being recycled. The teacher reads the definitions and teams take turns to guess the words (see Figure 2).

E.g. Students must guess these words: barter, plummet, outsource, agenda, commodity, trolley, expenditure, haggle, viable. Teacher reads the definitions: $B$ $=$ to exchange goods/services for other goods without using money; $P=$ to suddenly fall a long way, $O=$ to arrange for sb outside a company to do work or provide goods for the company, etc.

Figure 2: example of the use of games ${ }^{4}$

\subsection{Providing effective feedback}

The importance of teacher's feedback in shaping students' self-esteem, feelings of competence and therefore motivation cannot be underestimated. The teacher's feedback can be either oral or written and it can focus either on students' spoken or written performance (see Table 2). Whatever the case may be, it should always be positive, encouraging and focusing on effort, content, students' ideas and potential. Research in psychology indicates that rewards affect behaviour more than punishment does (Brown 2007: 85) and positive reinforcement often has more impact on students than negative reinforcement. On the other hand, holding students responsible and considering their efforts important (the idea of accountability) can result in making some students feel threatened. As Littlewood

\footnotetext{
${ }^{4}$ The author's idea
} 
(1984:59) notes "whereas too much anxiety hinders learning, it seems that a certain amount of it can stimulate a learner to invest more energy in the task".

For instance, when students speak, it is better if a teacher does not interrupt to correct for accuracy - he or she can take notes of the most relevant mistakes and go over them after the student has finished speaking. Sometimes when mistakes are recurrent among other learners, a teacher can do the corrective feedback with the whole class. If the mistake student has made hinders communication, a teacher can ask for clarification or rephrasing. When teachers correct students' written assignments, they must make sure they write comments which refer both to the language and the content. The feedback stage should be done with the whole class, rather than individually, in a form of a student-centred summarising activity at the end of the lesson in order to enable the uninterrupted flow of all the interactive activities. During the feedback stage the emphasis should less be on error correction and more on praising students for the good language use.

The current reward system (system of marks) is based on rewarding students with good marks or punishing them with bad marks. The main problem with this approach is that rewards only lead to sustained motivation. For the failing student, unlikely to be rewarded, it does not take long to work out that it is always someone else who gets the rewards, no matter how hard they try. The reward system itself can, therefore, be demotivating for the weaker students. The increase in the motivation of stronger students is more or less proportionate to the decrease in the motivation of weaker students. Since the reward system is methodologically flawed, teachers must rely on other means of assessment such as formative assessment ${ }^{5}$. Formative assessment is all about providing effective feedback. Teachers can come up with their own feedback forms in which they should assess their students' performance over a certain period of time (see Table 2). Dörnyei (2001b:124) points out the importance of positive information feedback which "involves positive, descriptive feedback regarding student strengths, achievements, progress and attitudes. Most importantly, this feedback provides students with information rather than judgements against external standards or peer achievement".

${ }^{5}$ Formative assessment is carried out during a course and it is designed to give feedback to the learners on strengths and weaknesses as the course progresses, rather than providing a final grade or report at the end of the course. (Nunan, 2015:187) 


\begin{tabular}{|c|c|c|c|c|c|c|}
\hline \multirow{2}{*}{$\begin{array}{l}\text { Student's } \\
\text { name }\end{array}$} & \multicolumn{2}{|c|}{$\begin{array}{l}\text { Legend: } \\
\text { S= speaking } W=\text { writing }\end{array}$} & \multicolumn{4}{|c|}{$\begin{array}{l}\text { Key: 4-very good, 3-good, 2-satisfactory, } \\
\text { 1-needs improvement }\end{array}$} \\
\hline & Date & Task & Content & Fluency & $\begin{array}{l}\text { Range of } \\
\text { vocabular } \\
y\end{array}$ & Accuracy \\
\hline \multirow{4}{*}{$X Y$} & $20^{\text {th }} \mathrm{Sept}$ & S: discussion & & 4321 & $4 \longdiv { 3 } 2 1$ & 4321 \\
\hline & $11^{\text {th }} \mathrm{Oct}$ & W: email & & $4 \longdiv { 3 } 2 1$ & $4 \longdiv { 3 } 2 1$ & 4321 \\
\hline & $3^{r d}$ Nov & $\begin{array}{l}\text { S: role-play } \\
\text { Telephone } \\
\text { conversation }\end{array}$ & & 4321 & 4321 & 43221 \\
\hline & $15^{\text {th }} \mathrm{Dec}$ & $\begin{array}{l}\text { W: describing a } \\
\text { person (para) }\end{array}$ & & 4321 & $4 \longdiv { 3 } 2 1$ & 4321 \\
\hline
\end{tabular}

Table 2: An example of the written feedback form ${ }^{6}$

For this purpose teachers must create a marking rubric and familiarize their students with it (see Table 3).

\begin{tabular}{|c|c|c|c|c|}
\hline & 4 & 3 & 2 & 1 \\
\hline FLUENCY & $\begin{array}{l}\text { Speech } \\
\text { continuous with } \\
\text { few pauses or } \\
\text { stumbling }\end{array}$ & $\begin{array}{l}\text { Some hesitation } \\
\text { but manages to } \\
\text { continue and } \\
\text { complete } \\
\text { thoughts }\end{array}$ & $\begin{array}{l}\text { Speech choppy } \\
\text { and/or } \\
\text { slow with } \\
\text { frequent pauses } \\
\text { few or no } \\
\text { incomplete } \\
\text { thoughts }\end{array}$ & $\begin{array}{l}\text { Speech halting } \\
\text { and uneven } \\
\text { with long } \\
\text { pauses or } \\
\text { incomplete } \\
\text { thoughts }\end{array}$ \\
\hline VOCABULARY & $\begin{array}{l}\text { Rich use of } \\
\text { vocabulary }\end{array}$ & $\begin{array}{l}\text { Adequate and } \\
\text { accurate use of } \\
\text { vocabulary for } \\
\text { this level }\end{array}$ & $\begin{array}{l}\text { Somewhat } \\
\text { inadequate } \\
\text { and/or } \\
\text { inaccurate use } \\
\text { of vocabulary } \\
\text { and too basic } \\
\text { for this level }\end{array}$ & $\begin{array}{l}\text { Inadequate } \\
\text { and/or } \\
\text { inaccurate use } \\
\text { of vocabulary }\end{array}$ \\
\hline$A C C U R A C Y$ & $\begin{array}{l}\text { Control of } \\
\text { basic language } \\
\text { structures }\end{array}$ & $\begin{array}{l}\text { Emerging } \\
\text { control of basic } \\
\text { language }\end{array}$ & $\begin{array}{l}\text { Emerging use } \\
\text { of basic } \\
\text { language }\end{array}$ & $\begin{array}{l}\text { Inadequate } \\
\text { and/or } \\
\text { inaccurate use }\end{array}$ \\
\hline
\end{tabular}

${ }^{6}$ The author's idea 


\begin{tabular}{|l|l|l|l|l|}
\hline & structures & structures & $\begin{array}{l}\text { of basic } \\
\text { language } \\
\text { structures }\end{array}$ \\
\hline
\end{tabular}

Table 3: An example of the marking rubric for the assessment of speaking

Teachers should avoid overemphasizing the importance of rewards which make students feel as if they are under external control and they lose their intrinsic motivation. Marks, test scores, extra points and other forms of rewards could be perceived by students as controlling. Therefore, teachers should not overemphasize the importance of these external rewards.

\section{BUILDING LEARNER AUTONOMY}

One of the primary teacher's roles is building learner autonomy, in other words, helping students to take charge of their own learning. The key to sustaining learner autonomy is to help students feel in control of their own behaviours, rather than feeling that teachers or peers are controlling them. "Having the opportunity to set at least some of their own goals in English study allows students to experience a degree of control over their own learning that helps enhance motivation" (Dörnyei 2001a:128). As Brown (2001: 70) notes,

Autonomy is now almost universally manifested in the classroom in the form

of allowing learners to do things like initiate oral production, solve problems

in small groups and produce language with peers.

Teachers can build learner autonomy by developing students' language learning strategies, which, according to Dörnyei (2001b: 95) refer to a range of specific learning techniques that make learning more effective and students can "hang on to" when feeling insecure. Dörnyei (2001b: 97) further summarises this as Strategy 26: Build your learners' confidence in their learning abilities by teaching them various learner strategies.

According to Oxford (1990: 272-275), language learning strategies fall into the following 6 categories: (1) memory strategies, (2) cognitive strategies, (3) compensation strategies (coping with problems), (4) metacognitive strategies (awareness of one's own learning process), (5) affective strategies (managing one's feelings), (6) social strategies (working with others). 
Chamot and O'Malley (1994: 60-64), have identified the following three categories:

- metacognitive strategies which learners use to plan, monitor and evaluate a learning task. Other examples include arranging the conditions that help one learn ("What conditions help you learn best?"), setting long-term and short-term goals ("What do you want to learn?") and checking one's comprehension during reading or listening ("What have you understood?").

- cognitive strategies which involve learners interacting and manipulating what is to be learned. Examples include replaying a word or phrase mentally to 'listen' to it again, outlining and summarizing what has been learned from reading or listening, and using keywords (remembering a new target language word by associating it with a familiar word or by creating a visual image of it);

- social-affective strategies where learners interact with other person/s or 'use affective control to assist learning'. Examples include creating situations to practise the target language with others, using self-talk, where one thinks positively and talks oneself through a difficult task, and cooperating and working with others to share information, obtain feedback and complete a task.

\section{CONCLUSION}

The language teacher plays a crucial role in creating a positive affective learning environment that enhances students' self-esteem, confidence and motivation. The teacher's communication style can affect students' motivation and weaken their sense of autonomy if perceived as controlling. The language teacher directly influences language learners' attitudes toward the subject. According to Brown (1987),

Second language learners benefit from positive attitudes and negative attitudes may lead to decreased motivation and, in all likelihood, because of decreased input and interaction, to unsuccessful attainment of proficiency. (Brown, 1987:127)

To avoid this, teachers can build intrinsic motivation by involving students, arousing and maintaining students' interest and providing effective feedback. Building intrinsic motivation results in greater self-esteem which again 
results in increased willingness to communicate and the ability to communicate is the ultimate goal of foreign language learning. Teachers can further build intrinsic motivation by building learner autonomy. This is achieved by developing students' language learning strategies which help students to take charge of their own learning and ultimately become independent from classroom.

In conclusion, motivation is conditio sine qua non of learning. There is no magic formula for sustaining motivation in learning. In a study of Hungarian EFL teachers, Dörnyei and Csizér aimed to empirically verify which of a list of intuitive strategies would be seen as most useful by teachers and to link it with a three-part framework of motivation (language, learner and learning situation level). The chosen strategies, called 'Ten Commandments' (Dörnyei and Csizér, 1998:203-229) include the following examples:

1 "Set a personal example with your own behaviour.

2 Create a pleasant, relaxed atmosphere in the class.

3 Present the tasks properly.

4 Develop a good relationship with the learners.

5 Increase the learners' linguistic self-confidence.

6 Make the language lessons interesting.

7 Promote learner autonomy.

8 Personalize the learning process.

9 Increase the learners' goal-orientedness.

10 Familiarize learners with the target language culture".

Rather than trying to adhere strictly to all ten commandments to spark their students' motivation, it is best if language teachers turned the classroom into a safe, nurturing place where students' self-worth is protected and where they can gain confidence. And the best way to build students' confidence is by providing regular dosages of success. As Dörnyei (2001b:89) notes,

It is a commonplace but very true that 'Success breeds success'. This suggests that a particularly important motivational strategy is creating multiple opportunities for the students to demonstrate positive features and to excel.

\section{REFERENCES}

Aronson, E., Blaney, N., Stephan C., Sikes, J., \& M. Snapp. (1978). The jigsaw classroom. Beverly Hills, CA: Sage Publishing Company.

Brown, H.D. (1987). Principles of language learning and teaching. $2^{\text {nd }}$ ed. New Jersey: Prentice Hall Regents. 
Brown, H.D. (2007). Teaching by principles: An interactive approach to language pedagogy. $3^{\text {nd }}$ ed.. New York: Pearson Longman.

Chamot, A.U., and M. O'Malley. (1994). The CALLA Handbook: How to implement the cognitive-academic language learning approach. Reading, MA: Addison Wesley Longman.

Council of Europe. (2001). Common European Framework of Reference for Languages: Learning, Teaching, Assessment. Pristupljeno 20.7.2014.URL: <http://www.coe.int/t/dg4/linguistic/Source/Framework_EN.pdf>

Crandall, J. A. (1999). Cooperative language learning and affective factors. In J. Arnold (Ed.), Affect in language learning. Cambridge: Cambridge University Press, (226-245).Dörnyei, Z., and K. Csizér. (1998). Ten commandments for motivating language learners: Results of an empirical study. Language Teaching Research 2: 203-229.

Dörnyei, Z. (2001a). Teaching and researching motivation. Harlow, England: Pearson Education.

Dörnyei, Z. (2001b). Motivational strategies in the language classroom. Cambridge: Cambridge University Press.

Harmer, J. (2001). The practice of English language teaching. Harlow, England: Pearson Education.

Vesna O. Despotović

\section{NASTAVNIK KAO NAJVAŽNIJI FAKTOR MOTIVACIJE U NASTAVI STRANOG JEZIKA}

\section{Sažetak}

Cilj rada je da ukaže na značaj koncepta motivacije u nastavi stranog jezika i nastavnika kao ključnog faktora motivacije učenika. Uključivanjem u rad svih učenika, postizanjem i održavanjem stepena zainteresovanosti učenika i efikasnim pružanjem povratnih informacija, nastavnik je u stanju da utiče na rast unutrašnje motivacije učenika koja je ključ za učenje stranog jezika. Na primer, nastavnik može da motiviše učenike tako što će im omogućiti da što češće biraju (teme, aktivnosti, domaće zadatke, vokabular, rad u paru ili grupi). Nastavnik takođe može da koristi različite strategije sa ciljem da stvori pozitivno okruženje koje podstiče samopouzdanje i motivaciju učenika kao što su tehnike kooperativnog učenja, aktivnosti koje podstiču razvoj kritičkog mišljenja pa čak i igre. Konačno, razvijanjem strategija učenja stranog jezika, nastavnik je u stanju da direktno utiče na jačanje autonomije učenika koja vodi stalnoj motivaciji u učenju. Kao ilustraciju, autor navodi primere samo-ocenjivanja, upotrebe igara, upotrebe kritičkog mišljenja, formulara za pružanje povratnih informacija i rubriku odnosno kriterijumsko-referentnu listu za ocenjivanje. Sve ove tehnike pomažu učenicima u izgradnji autonomije i u preuzimanju odgovornosti za sopstveno učenje. Ključna stvar u održavanju učeničke 
autonomije je prebacivanje težišta odgovornosti sa nastavnika i vršnjaka na samog učenika. Ovo se može postići razvojem strategija učenja, što se u radu takođe ilustruje. Sve u svemu, nastavnik igra presudnu ulogu u stvaranju pozitivnog okruženja za učenje i time pojavačava samopouzdanje i motivaciju učenika i pretvara učionicu u bezbedno mesto u kome motivacija učenika raste i razvija se.

Ključne reči: jezik, učenje, motivacija, učenici, nastavnik.

Primljeno: 14.3.2017. Prihvaćeno: 10.11.2017. 